\section{Perlindungan Hukum Terhadap Karya Cipta Lagu "Hilang" Atas Tindakan Perbanyakan Atas Karya Cipta Tanpa Perjanjian Lisensi (Studi Putusan Mahkamah Agung Republik Indonesia Nomor 192 PK/Pdt.Sus/2010)}

$$
\text { oleh: }
$$

\section{Khairil Fahmi ${ }^{1}$}

\section{Abstract}

The development of human creativity in creating a work that can have economic value requires legal protection. This protection is very important to encourage the creative enthusiasm of people.

There are some basic principles of the copyright law protection of the sound recordings results in its protection that need to be considered, such as what is protected by copyright is an idea that has been tangible and original. As a result of law enforcement efforts against piracy song or music copyright is regulated in the Article 72 where the law enforcement efforts by the government by providing criminal sanctions and civil sanctions with claims for compensation, the Supreme Court considers the reasons of the Petitioner for Review that these reasons cannot be justified, because the judex juris did not commit an error or a real mistake in deciding the a quo case. In general, the forms of Song or Music copyright piracy are divided into several categories, namely Pirate, Couterfeit and Bootleging. The motive for the piracy is for commercial interests in the form of financial gain. The role of the government in law enforcement dealing with piracy is to provide strict sanctions in the form of confiscation and destruction of goods resulting from Copyright piracy carried out by the government.

Keywords: Legal Protection, Copyright, Songs, Propagation Actions, License.

\section{Abstrak \\ Perkembangan kreativitas manusia dalam menciptakan suatu karya yang dapat mempunyai nilai ekonomis membutuhkan}

perlindungan hukum. Perlindungan ini sangat penting untuk mendorong gairah inovasi orangorang yang kreatif.

Perlindungan hukum hak cipta terhadap hasil rekaman suara dalam perlindungannya ada beberapa prinsip dasar yang perlu diperhatikan, yakni yang dilindungi hak cipta adalah ide yang telah berwujud dan asli, Akibat dari upaya penegakan hukum terhadap pembajakan Hak Cipta Lagu atau Musik di atur dalam Pasal 72, dimana upaya penegakan hukum oleh pemerintah dengan memberikan sanksi pidana dan sanksi perdata dengan tuntutan ganti rugi, Mahkamah Agung mempertimbangkan alasanalasan dari Pemohon Peninjauan Kembali bahwa Alasan-alasan tersebut tidak dapat dibenarkan, oleh karena judex juris tidak melakukan kekhilafan atau kekeliruan nyata memutus perkara a quo. Secara umum bentukbentuk pembajakan Hak Cipta Lagu atau Musik terbagi atas beberapa kategori yaitu Pirate, Couterfeit dan Bootleging. Motif pembajaka tersebut adalah untuk kepentingan dagang berupa keuntungan financial. Peranan pemerintah dalam penegakan hukum guna menangani pembajakan adalah dengan memberikan sanksi yang tegas berupa perampasan dan pemusnahan barang hasil pembajakan Hak Cipta yang dilakukan oleh pemerintah.

Kata Kunci : Perlindungan Hukum, Karya Cipta, Lagu, Tindakan Perbanyakan, Lisensi.

\section{PENDAHULUAN}

\section{A. Latar Belakang}

Negara Indonesia adalah negara hukum, artinya segala tindakan yang dilakukan oleh masyarakat Indonesia harus berdasarkan hukum yang berlaku di negara Indonesia. Penerapan hukum dengan cara menjunjung tinggi nilai-nilai yang terdapat dalam Pancasila, merupakan suatu upaya untuk meningkatkan kualitas manusia dan masyarakat Indonesia, dengan memanfaatkan ilmu pengetahuan dan

\footnotetext{
${ }^{1}$ Alumni Fakultas Hukum UISU
} 
Media Komunikasi dan Informasi Hukum dan Masyarakat

teknologi serta memperhatikan perkembangan globalisasi yang modern.

Perkembangan kreativitas manusia dalam menciptakan suatu karya yang dapat mempunyai nilai ekonomis membutuhkan perlindungan hukum. Perlindungan ini sangat penting untuk mendorong gairah inovasi orangorang yang kreatif.

Hak Kekayaan Intelektual (selanjutnya disingkat HKI) merupakan jawaban terhadap Perlindungan hukum tersebut. Indonesia telah ikut dalam pergaulan masyarakat dunia dengan menjadi anggota dalam Agreement Establishing The World Trade Organization (Persetujuan Pembentukan Organisasi Perdagangan Dunia) yang mencakup pula Agreement on Trade Related Aspects of Intellectual Property Rights (Persetujuan tentang Aspek-Aspek Dagang Hak Kekayaan Intelektual), (selanjutnya disingkat TRIPs) melalui Undang-Undang Nomor 7 Tahun 1994.

Di samping itu kemajuan teknologi rekaman seperti mesin fotocopi dan mesin rekaman audio dan video serta kemajuan teknologi di bidang grafika dengan mudah dan biaya murah dapat mengadakan karya-karya ciptaan dengan cepat sehingga para penciptanya atau pemegang hak ciptanya sulit melakukan pengawasan atas pengkopian ciptaannya yang dilakukan secara tidak sah. "Seorang pencipta diberi kesempatan untuk memonopoli penggandaan dari karya ciptanya berupa copyright agar ia berkesempatan memperoleh manfaat ekonomi atas hasil kreatifitasnya". ${ }^{2}$

Sementara itu kehidupan teknologi terus berkembang dengan antara lain penerapan

${ }^{2}$ Agus Sardjono, 2009, Membumikan HKI di Indonesia, Nuansa Aulia, Bandung, h. 146153. komputer dan satelit di bidang teknologi informasi dan komunikasi yang jangkauan informasi makin meluas meliputi wilayah antar negara dan antar benua. Dalam keadaan seperti itu hak milik intelektual, khususnya hukum hak cipta tidak sesuai lagi dan memerlukan penyesuaian-penyesuaian sesuai dengan langkah kemajuan teknologi. ${ }^{3}$

Musik dianggap sebagai salah satu sarana pengembang kreativitas yang lebih mudah masuk ke dalam sendi -sendi masyarakat dari berbagai kalangan status ekonomi dan usia. Konser dan jenis-jenis pertunjukan lain sudah menjadi cara yang cepat bagi para musisi untuk meningkatkan penghasilan. Hal ini memberi nilai tambah tersendiri. "Dalam musik, ikatan emosional terbangun dengan orang-orang di panggung yang mengangan-angankan sesuatu yang indah atau mempesona dari alat-alat musik maupun suara sang musisi, baik pop maupun genre musik lain". ${ }^{4}$

Konsepsi mengenai HKI didasarkan pada pemikiran bahwa karya intelektual yang telah dihasilkan manusia memerlukan pengorbanan tenaga, waktu, dan biaya. Adanya pengorbanan tersebut menjadikan karya yang telah dihasilkan memiliki nilai ekonomi karena manfaat yang dapat dinikmati. Berdasarkan konsep tersebut, maka mendorong kebutuhan adanya penghargaan atas hasil karya yang telah dihasilkan berupa perlindungan hukum bagi HKI. Tujuan pemberian perlindungan hukum ini untuk mendorong dan Menumbuh kembangkan semangat berkarya dan mencipta. ${ }^{5}$

${ }^{3}$ Harsono Adisumarto, Hak Milik Intelektual kususnya Hak Cipta, Akademik Pressindo, Jakarta, h. 48.

${ }^{4} J o o s t$ Smiers Marieke van Schijndel, 2012, Dunia Tanpa Hak Cipta, Jogjakarta, h.117 ${ }^{5}$ Ahmad M.Ramli, 2000, H.A.K.I Hak Atas Kepemilikan Intelektual, Teori Dasar Perlindungan Rahasia Dagang, Mandar Maju, Bandung, h 4 
Media Komunikasi dan Informasi Hukum dan Masyarakat

Berkaitan dengan pemberian royalti kepada Pencipta lagu atau musik atas hasil karya ciptaannya, diperlukan dasar hukum untuk memperoleh hak tersebut. UUHCPasal 35 mengatur:

(1) Kecuali diperjanjikan lain Pemegang Hak Cipta atas Ciptaan yang dibuat oleh Pencipta dalam hubungan dinas, yang dianggap sebagai Pencipta yaitu instansi pemerintah

(2) Dalam hal Ciptaan sebagaimana dimaksud pada ayat (1) digunakan secara komersial, Pencipta dan/atau Pemegang Hak Terkait mendapatkan imbalan dalam bentuk Royalti.

(3) Ketentuan lebih lanjut mengenai pemberian Royalti untuk penggunaan secara komersial sebagaimana dimaksud pada ayat (2) diatur dengan Peraturan Pemerintah.

Di dalam industri musik, Royalti dibedakan antara :

a. Royalti (royalti payment) yaitu sistem pembayaran atau kompensasi secara bertahap, baik dengan / tanpa uang muka atau advance bagi penggunaan sebuah ciptaan. Pembayaran jenis ini harus mengikuti omset penjualan secara terus menerus selama produknya dijual di pasaran

b. Flat (flat payment) adalah sistem pembayaran langsung atau tidak bertahap. Dengan kata lain, royalti dibayarkan secara sekaligus atas penggunaan sebuah karya cipta musik. Pembayaran jenis ini harus ditentukan jumlah dan jangka waktu peredarannya. ${ }^{6}$

Perlindungan hak cipta khususnya terhadap ciptaan musik atau lagu menjadi masalah serius, sebab Indonesia dikategorikan masuk sebagai salah satu Negara yang tingkat pembajakan cukup besar. Keadaan tersebut menunjukkan bahwa masih perlunya

${ }^{6}$ Husain Audah, 2004, Hak Cipta dan Karya Musik, PT Pustaka Litera Antar Nusa, Jakarta, h. 59 perlindungan hukum yang lebih tegas terkait perlindungan atas royalti suatu karya cipta lagu atau musik serta perlindungan hak-hak yang terkandung di dalamnya.

Persatuan Artis Penyanyi, Pencipta Lagu dan Penata Musik Rekaman Indonesia (PAPPRI) memiliki catatan. Dari data mereka, karya cipta berupa musik yang dibajak sepanjang tahun 2007 mencapai 500 juta keping baik untuk Compact Disk (CD) dan Music Player 3 maupun kaset. Angka itu meningkat dibanding tahun 2006 yang jumlahnya 400 juta keping. Akibat pembajakan itu, kerugian artis dan produser ditaksir mencapai Rp2,5 triliun.

Suatu aturan hukum yang dibuat oleh lembaga legislatif akan membawa pengaruh pada masyarakat. Aturan hukum dalam hal ini undang-undang dapat dikatakan baik, belumlah cukup apabila hanya dipandang dari persyaratan filosofis/idiologis dan yuridis akan tetapi undang-undang tersebut harus berlaku secara efektif. Penelitian tentang efektivitas peraturan perundang-undangan pada dasarnya merupakan penelitian pembanding antara realitas hukum dan ideal hukum.

\section{B. Rumusan Masalah}

Berdasarkan latar belakang diatas, maka ditentukan perumusan masalah sebagai berikut:

1. Bagaimana implementasi perlindungan hukum terhadap pemegang hak cipta atas karya cipta lagu ditinjau dari Undang-Undang Republik Indonesia Nomor 28 Tahun 2014?

2. Apa akibat hukum atas tindakan perbanyakan lagu hilang tanpa perjanjian lisensi ditinjau dari Undang-Undang Republik Indonesia Nomor 28 Tahun 2014?

3. Bagaimana pertimbangan hakim terhadap pencipta lagu "hilang" dalam putusan 
Media Komunikasi dan Informasi Hukum dan Masyarakat

Mahkamah Agung Republik Indonesia Nomor 192 PK/Pdt.Sus/2010?

\section{Tujuan Penelitian}

Adapun yang menjadi tujuan penelitian dalampenulisan tesis ini adalah:

1. Untuk mengkajiimplementasi perlindungan hukum terhadap pemegang hak cipta atas karya cipta lagu ditinjau dari Undang-Undang Republik Indonesia Nomor 28 Tahun 2014.

2. Untuk mengkajiakibat hukum atas tindakan perbanyakan lagu hilang tanpa perjanjian lisensi ditinjau dari Undang-Undang Republik Indonesia Nomor 28 Tahun 2014.

3. Untuk mengkajipertimbangan hakim terhadap pencipta lagu "hilang" dalam putusan Mahkamah Agung Republik Indonesia Nomor 192 PK/Pdt.Sus/2010?

\section{Manfaat Penelitian}

Melalui Penelitian ini diharapkan dapat memberikan manfaat baik secara teoritis, normatif maupun praktis, yakni ;

1. Secara teoritis, hasil penelitian ini dapat menyumbangkan pemikiran dibidang hukum dalam lapangan hak kekayaan intelektual khusus terhadap hak ciptaterkhusus terhadap karya cipta musik (lagu).

2. Secara praktis, hasil penelitian ini dapat digunakan oleh Pemerintah khususnya Direktorat Jenderal Kekayaan Intelektual dalam mengambil keputusan mengenai penerimaan hak dalam pendaftaran hak baru ataupun dalam melakukan pengawasan penggunaan hak yang tengah dilindungi hak cipta.

\section{E. Kerangka Teori dan Kerangka Konsep}

\section{Kerangka Teori}

Kerangka teoritik dan sebagainya, berbagai istilah tersebut pada dasarnya sama maksud dan maknanya, mungkin ada yang lebih luas dan yang lain lebih sempit kajiannya, akan tetapi isi dari kerangka teoritik adalah konsepsikonsepsi, teori-teori, pandangan-pandangan, dan penemuan yang relevan dengan pokok permasalahan. ${ }^{7}$

Kata teoritik atau teoritis atau theorical berarti berdasarkan pada teori, mengenai atau menurut teori. ${ }^{8}$ Kata teori berasal dari kata theoria dalam bahasa Latin yang berarti perenungan. Kata theoria itu sendiri berasal dari kata thea yang dalam bahasa Yunani berarti cara atau hasil pandang. ${ }^{9}$ Dalam penelitian ilmiah, adanya kerangka teoritis adalah merupakan suatu kerangka dari mana suatu masalah dan hipotesis diambil atau dihubungkan.

Peter Mahmud Marzuki menyatakan bahwa:"Penelitian hukum dilakukan untuk menghasilkan argumentasi, teori ataupun konsep baru sebagai preskrepsi dalam menyelesaikan masalah yang dihadapi."10 Kedudukan teori dalam suatu penelitian hukum sangat penting, di mana teori membuat jelas nilai-nilai oleh postulat-postulat hukum sampai kepada landasan filosofisnya yang tertinggi. ${ }^{11}$

${ }^{7}$ Mukti Fajar ND dan Yulianto Achmad, Dualisme Penelitian Hukum Normatif \& Empiris, Pustaka Pelajar, Yogyakarta, 2010, h. 92.

${ }^{8}$ Sudikno Mertokusumo, Penemuan Hukum Sebuah Pengantar, Liberty, Yogyakarta, 2001, h. 156

${ }^{9}$ Soetandyo Wigjosoebroto, Hukum, Paradigma, Metode dan Dinamika Masalahnya, Elsam HuMa, Jakarta, 2002, h. 184

${ }^{10}$ Peter Mahmud Marzuki, Penelitian Hukum, Jakarta: Kencana Prenada Media, Jakarta, 2010, h. 35

${ }^{11}$ Satjipto Rahardjo, IImu Hukum, Citra Aditya Bakti, Bandung, 2010, h. 254. 
Media Komunikasi dan Informasi Hukum dan Masyarakat

\section{a. Teori Perlindungan Hukum}

Konsep hukum sangat dibutuhkan apabila mempelajari hukum.Konsep hukum pada dasarnya adalah batasan tentang suatu istilah tertentu.Tiap istilah ditetapkan arti dan batasan maknanya setajam dan sejelas mungkin yang dirumuskan dalam suatu definisi dan digunakan secara konsisten.Konsep yuridis (legal concept) yaitu konsep konstruktif dan sistematis yang digunakan untuk memahami suatu aturan hukum atau sistem aturan hukum.

Menurut Subekti sebagaimana dikutip oleh C.S.T. Kansil bahwa hukum itu mengabdi pada tujuan Negara yang dalam pokoknya ialah mendatangkan kemakmuran dan kebahagiaan pada rakyatnya. Tujuan Negara tersebut dengan menyelenggarakan "keadilan" dan "ketertiban", syarat-syarat yang pokok untuk mendatangkan kemakmuran dan kebahagiaan. ${ }^{12}$

Salah satu tujuan hukum adalah mewujudkan keadilan sebagai syarat untuk mendatangkan kemakmuran dan kebahagiaan bagi masyarakat. Berawal dari statemen tersebut, maka pandangan awal tentang terwujudnya tujuan hukum adalah penegakan hukum. Penegakan hukum merupakan salah satu usaha untuk mencapai atau menciptakan tata tertib, keamanan dan ketentraman dalam masyarakat baik itu merupakan usaha pencegahan maupun pemberantasan atau penindakan setelah terjadinya pelanggaran hukum, dengan perkataan lain baik secara preventif maupun represif.

Soedjono Dirjosisworo, menjelaskan:

Tujuan hukum adalah melindungi kepentingan-kepentingan manusia. Akan tetapi justru oleh kareana kepentingan-

${ }^{12}$ C.S.T. Kansil, Pengantar IImu Hukum Dan Tata Hukum Indonesia, Balai Pustaka, Jakarta, 2007, h. 41. kepentingan itu saling bertentangan, maka tidaklah mungkin hukum itu dapat memberi perlindungan penuh terhadap kepentingan-kepentingan yang satu, serta mengabaikan kepentingan orang yang lain. Karena bulankah, perlindungan sepenuhnya dari kepentingan orang yang satu, berarti pengabaian kepentingan orang, yang lain sebagian atau seluruhnya. ${ }^{13}$

Menurut Sudikno Mertokusumo dalam Ridwan HR, hukum berfungsi sebagai perlindungan kepentingan manusia. Agar kepentingan manusia terlindungi, hukum harus dilaksanakan. Pelaksanaan hukum dapat berlangsung secara normal, damai, tetapi dapat terjadi juga karena pelanggaran hukum. ${ }^{14}$

Adanya perbedaaan kepentingan manusia yang saling bertentangan, maka hukum itu mencari jalan untuk memecahkan soal itu, yakni dengan mempertimbangkan seteliti-telitinya kedua jenis kepentingan yang bertentangan itu, sehingga terdapat keseimbangan. Jadi hukum itu menunjukkan usahanya pada penyelesaian yang mengadakan keseimbangan antara kepentingan-kepentingan yang pada hakikatnya bertentangan, sehingga masing-masing memperoleh sebanyakbanyaknya apa yang patut diterima yang hakikatnya tidak dapat memberi kepuasan untuk semua pihak. ${ }^{15}$

\section{Kerangka Konsep}

Menghindari terjadinya perbedaan pengertian tentang konsep yang dipakai dalam penelitian ini, perlu dikemukakan mengenai pengertian konsep yang akan digunakan, sebagai berikut:

${ }^{13}$ Soedjono Dirjosisworo, Pengangtar IImu Hukum, Rajawali Pers, Jakarta, 2013, h. 11

${ }^{14}$ Ridwan HR, Hukum Adminitrasi Negara, Rajawali Pers, Jakarta, 2006, h. 280

${ }^{15}$ Soedjono Dirjosisworo. Op. Cit,. h. 11 
Media Komunikasi dan Informasi Hukum dan Masyarakat

a. Perlindungan hukum adalah

Upaya perlindungan yang diberikan terhadap subyek hukum dalam bentuk perangkat hukum baik yang bersifat preventif maupun yang bersifat represif, baik yang tertulis maupun tidak tertulis. Dengan kata lain perlindungan hukum sebagai suatu gambaran dari fungsi hukum. yaitu konsep dimana hukum dapat memberikan suatu keadilan, ketertiban, kepastian, kemanfaatan dan kedamaian. ${ }^{16}$

b. Ciptaan menuurt Pasal 1 Angka 3 UUHC adalah "setiap hasil karya cipta di bidang ilmu pengetahuan, seni, dan sastra yang dihasilkan atas inspirasi, kemampuan, pikiran, imajinasi, kecekatan, keterampilan, atau keahlian yang diekspresikan dalam bentuk nyata".

c. Lagu adalah sastra yang sangat istimewa, karena tempo lagu menunjukkan setiap kedalaman makna. Lirik- lirik pada lagu bersifat manis, sehingga dapat membuat orang-orang merasa terbang, tergelincir, ringan dan naif. ${ }^{17}$

d. Pembajakan menurut Pasal 1 Angka 23 UUHC adalah "Pengadaan ciptaan dan/atau produk Hak Terkait secara tidak sah dan pendistribusian barang hasil penggandaan dimaksud secara luas untuk memperoleh keuntungan ekonomi".

e. Lisensi menurut Pasal 1 Angka 20 UUHC adalah izin tertulis yang diberikan oleh Pemegang Hak Cipta atau Pemilik Hak Terkait kepada pihak lain untuk melaksanakan hak ekonomi atas

${ }^{16}$ Anonim, "Seputar Pengertian Perlindungan Hukum", Diakses melalui: seputar pengertian.blog.spot.com> Hukum Perlindungan, tanggal 01 Desember 2018.

${ }^{17}$ https://eprints.uny.ac.id/13360/3/BAB\%2 0ll.PDF diakses pada tangga; 01 Desember 2018, h. 2.
Ciptaannya atau produk Hak Terkait dengan syarat tertentu.

\section{F. Keaslian Penelitian}

Berdasarkan penelusuran yang dilakukan di perpustakaan Universitas Islam Sumatera Utara dan browsing melalui internet terdapat beberapa penelitian yang telah dilakukan oleh penelitian terdahulu, yang berkaitan dengan judul dan permasalahan yang menjadi objek kajian dalam penulisan tesis ini. Adapun beberapa penelitian yang memiliki keterkaitan dengan objek penelitian ini adalah:

1. SkripsiPrimadhia Lerai Marista, NPM: E1A008215, mahasiswa Fakultas Hukum Universitas Jenderal Soedirman, Purwokerto, 2012.

Judul tesis yang menjadi topik/tema dalam penelitian tesis ini adalah mengenai:Pembatalan Pendaftaran Hak Cipta Berdasarkan Gugatan Pencipta Atau Pemegang Hak Cipta (Studi Terhadap Putusan Mahkamah Agung Nomor 768 K/Pdt.Sus/2010.

Adapun yang menjadi permasalahan dalam penelitian ini adalah penerapan Pasal 42 Undang - Undang Nomor 19 Tahun 2002 Tentang Hak Cipta Dalam Putusan Mahkamah Agung Nomor 768 K/Pdt.Sus/2010.

2. Tesis Andri Ardiyan Mustakim, NPM: 1320312074,Mahasiswa Program Studi Hukum Islam Konsentrasi Hukum Bisnis Syariah UIN Sunan Kalijaga, Yogyakarta. Judul penelitian/tesis: "Pembajakan Soft Copy Karya Tulis IImiah (Studi Terhadap Pelanggaran Hak Cipta Dalam Hukum Positif dan Hukum Islam di Yogyakarta)" 
Media Komunikasi dan Informasi Hukum dan Masyarakat

Adapun yang menjadi permasalahan dalam penelitian ini, yaitu: analisis yuridis pembajakan soft copy karya tulis ilmiah di Yogyakarta. analisis normatif pembajakan soft copy karya tulis ilmiah di Yogyakarta. hukum jual beli hasil pembajakan soft copy karya tulis ilmiah dalam hukum Islam.

Berdasarkan peninjauan yang telah dilakukan, maka sejauh yang diketahui, penelitian tentang: Perlindungan Hukum Terhadap Karya Cipta Lagu "Hilang" Atas Tiindakan Perbanyakan Atas Karya Cipta Tanpa Perjanjian Lisensi (Studi Putusan Mahkamah Agung Republik Indonesia Nomor 192 PK/Pdt.Sus/2010)belum pernah dilakukan baik dilihat dari judul maupun dari subtansi permasalahan Sehingga penelitian ini adalah asli adanya. Artinya, secara akademik penulisan ini dapat dipertanggungjawabkan kemurniannya

\section{G. Metode Penelitian}

\section{Jenis dan Alat Penelitian}

Penelitian hukum dibedakan dalam dua bentuk, yakni penelitian normatif dan penelitian empiris (sosiologis). ${ }^{18}$ Penelitian ini merupakan penelitian yuridis normatif. Melalui penelitian hukum yuridis normatif, maka dapat diketahui apakah peraturan perundangan yang berlaku saat ini mengenai kebijakan pendaftaran karya cipta agar mendukung terciptanya kepastian hukum dan perlindungan hukum terhadap hak cipta. Sehingga terciptanya tertib adiministrasi di bidang pertanahan, juga dapat meminimalisir terjadinya sengketa atas hak cipta serta

${ }^{18}$ Soerjono Soekanto, Penelitian Hukum Normatif Suatu Tinjauan, Jakarta, Rajawali Pers, 2013, h. 12. memberikan perlindungan hukum terhadap pemegang hak cipta.

Penelitian hukum normatif bertujuan untuk mengetahui apakah hukum di bidang hak cipta yang saat ini berlaku telah mampu memberikan kepastian hukum dan perlindungan hukum terhadap kepemilikan atas hak cipta.

Penelitian terhadap asas-asas hukum, yaitu suatu telaah terhadap unsur-unsur hukum (gegevens van het recht). Unsur-unsur hukum tersebut meliputi unsur idiel dan unsur riil. Unsur idiel mencakup hasrat susila dan rasio manusia. Sedangkan unsur riil mencakup manusia, kebudayaan (materiil) dan lingkungan alam, yang menghasilkan tata hukum. ${ }^{19}$

Penelitian ini bersifat deskriptif analitis dengan studi observasional untuk memberikan gambaran mengenai penelitian yang dilakukan dengan mengamati kondisi-kondisi yang terjadi dengan observasi langsung.

\section{Metode Pendekatan}

Penelitian ini menggunakan pendekatan normatif, yaitu dengan menganalisis permasalahan berdasarkan undang-undang (statute approach) pendekatan konseptual (conceptual approach). Pendekatan undangundang (statute approach) dilakukan dengan menganalisis permasalahan dan pembahasan berdasarkan peraturan perundang-undangan, dalam hal ini adalah Undang-Undang Hak Cipta dan peraturan perundang-undangan yang relevan dengan permasalahan yang dikemukakan dan pembahasan penelitian.

\section{Sumber Data}

Jenis data penelitian ini adalah primer dan sekunder. Data primer adalah data yang diperoleh langsung studi pustaka dan studi

\footnotetext{
${ }^{19}$ lbid.
} 
Media Komunikasi dan Informasi Hukum dan Masyarakat

putusan. Data sekunder dalam penelitian ini bersumber dari :

a. Bahan hukum primer, yaitu bahan hukum berupa peraturan perundang-undangan mengenai pembatalan atas hak cipta terdaftar.

b. Bahan hukum sekunder yaitu bahan-bahan yang erat hubungannya dengan bahan hukum primer berupa buku-buku yang berhubungan dengan objek yang diteliti

c. Bahan hukum tertier yakni yang memberikan informasi lebih lanjut mengenai bahan hukum primer dan bahan hukum sekunder seperti kamus hukum.

\section{Teknik dan Alat Pengumpulan Data}

Pengumpulan data dalam penelitian ini dilakukan dengan melaksanakan penelitian kepustakaan (library reseacrh), yaitu dengan metode pendekatan konseptual (conceptual approach)

\section{Analisis Data}

Analisis data dalam penelitian ini menggunakan analisis data kualitatif. Analisis data kualitatif adalah upaya yang dilakukan dengan jalan bekerja dengan data, mengorganisasikan data, memilah-milahnya menjadi satuan yang dapat dikelola, mensintesiskannya, mencari dan menemukan pola, menemukan apa yang penting dan apa yang dipelajari dan memutuskan apa yang dapat diceritakan kepada orang lain.

Analisis data kualitatif adalah upaya yang dilakukan dengan jalan bekerja dengan data, mengorganisasikan data, memilah-milahnya menjadi satuan yang dapat dikelola, mensintesiskannya, mencari dan menemukan pola, menemukan apa yang penting dan apa yang dipelajari.
Pelaksanaan analisis data dalam penelitian ini, terdapat 3 (tiga) aspek kegiatan yang penting, yaitu: menulis catatan, mengidentifikasi konsep-konsep dan mengembangkan batasan konsep dan teori.

\section{H. Sistematika Penulisan}

Untuk memudahkan pembahasan tesis ini maka penulis akan membuat sistematika secara teratur dalam bagian-bagian yang semuanya saling berhubungan satu dengan yang lainnya

\section{Pembahasan}

1. Implementasi Perlindungan Hukum Terhadap Pemegang Hak Cipta Atas Karya Cipta Lagu Ditinjau Dari Undang Undang Republik Indonesia Nomor 28 Tahun 2014

\section{A. Pembatasan Ruang Jangkauan Pembajakan Pada Karya Lagu}

Menurut ketentuan Pasal 18 UUHC bahwa : "ciptaan buku, dan/atau semua hasil karya tulis lainnya, lagu dan/atau musik dengan atau tanpa teks yang dialihkan dalam perjanjian jual putus dan/atau pengalihan tanpa batas waktu, hak ciptanya beralih kembali kepada pencipta pada saat perjanjian tersebut mencapat jangka waktu 25 (dua puluh lima) tahun."

Suatu kreasi intelektual dalam bidang seni, sastra dan ilmu pengetahuan dapat melahirkan hak cipta. Hak Cipta adalah hak eksklusif bagi pencipta atau penerima hak untuk mengumumkan atau memperbanyak ciptaan atau memberikan izin untuk itu dengan tidak mengurangi pembatasan-pembatasan menurut peraturan perundang-undangan yang berlaku.

Sebagaimana pendapat L.J. Taylor yang dikutif oleh Damian yang menyatakan bahwa 
Media Komunikasi dan Informasi Hukum dan Masyarakat

"hak cipta melindungi suatu ekspresi dari sebuah ide, sedangkan ide yang belum diwujudkan belum dilindungi". ${ }^{20}$ Dari pengertian ini sangat jelas bahwa hak cipta diberikan hanya pada karya-karya yang merupakan penuangan ide secara nyata, bukan sekedar gagasan dan ide semata. Pengertian hak cipta yang diuraikan di atas selain memberikan pemahaman tentang hak cipta dalam pengertian itu menunjukkan karakteristik dari hak cipta. Karakteristik hak cipta mencakup pada:

1. Pemegang hak cipta terdiri dari pencipta atau penerima hak;

2. Hak eksklusif untuk mengumumkan atau memperbanyak;

3. Dapat diberikan hak eksklusif tersebut kepada pihak lain dengan memberi izin;

4. Hak cipta timbul secara otomatis; hak cipta mencakup pada bidang seni, sastra dan ilmu pengetahuan.

Hak cipta memiliki dua macam hak, yakni hak moral dan hak ekonomi. Hak moral adalah hak yang melekat pada diri pencipta. Hak moral diatur di dalam ketentuan Pasal 24 ayat (1), (2), (3), dan (4) UU Hak Cipta. Dari ketentuan ini dapat ditetapkan bahwa moral meliputi pada:

1. Nama pencipta harus dicantumkan dalam ciptaannya;

2. Ciptaan tidak boleh diubah kecuali atas persetujuan pencipta atau ahli waris;

3. Nama pencipta atau nama samaran pencipta tidak boleh dilakukan perubahan;

4. Judul dan anak judul ciptaan tidak boleh dilakukan perubahan.

${ }^{20}$ Damian, Eddy, 2010, Op.Cit., h. 19
Muhammad Djumhana mengemukakan bahwa hak moral adalah hak-hak yang melindungi kepentingan pribadi si pencipta. Konsep hak moral ini berasal dari sistem hukum Kontinental, yaitu Perancis. Menurut konsep hukum Kontinental hak pengarang (droit d'auteur, author rights) terbagi menjadi hak ekonomi untuk mendapatkan keuntungan yang bernilai ekonomi seperti uang, dan hak moral yang menyangkut perlindungan atas reputasi si pencipta. Di setiap negara umumnya hak ekonomi di dalam hak cipta terdiri dari: hak reproduksi atau penggandaan, hak adaptasi, hak distribusi, hak penampilan (performance rights), hak penyiaran (broadcasting right), hak program kabel, droit de suite, dan hak pinjam masyarakat (public lending rights).

Lingkup hak cipta meliputi pada bidang seni, sastra dan ilmu pengetahuan. Pasal 12 ayat (1) UU Hak Cipta menentukan jenis-jenis ciptaan yang diberikan hak cipta secara terperinci. Penetapan beberapa jenis ciptaan yang diberikan hak cipta ini sebenarnya tidak membatasi atas pemberian hak cipta atas ciptaan lain di luar yang ditetapkan berdasarkan ketentuan Pasal 12 ayat (1) UU Hak Cipta.

\section{B. Sanksi Bagi Pelanggar Hak Cipta Lagu}

Hukum material yang telah ditetapkan tidak akan berjalan efektif sebagaimana diharapkan apabila tidak dilengkapi dengan ketentuan aturan formal tentang bagaimana menegakkan hukum material di dalam kehidupan sehari-hari masalah penegakan hukum merupakan sisi lain dari sistem perlindungan hak cipta, sehingga perlu dilengkapi dengan berbagai ketentuan yang memadai untuk dijadikan pegangan.

Penegakan hukum hak cipta dimaksudkan tidak lain untuk mewujudkan cita- 
Media Komunikasi dan Informasi Hukum dan Masyarakat

cita hukum yang terkandung di dalam Undangundang Hak Cipta. Dengan kata lain dimaksud untuk mencapai tujuan perlindungan hak cipta itu sendiri. Apabila tujuan itu tidak terlaksana maka ada pihak-pihak tertentu yang mendapatkan kerugian-kerugian ini terjadi akibat adanya pelanggaran hukum hak cipta. Pihak-pihak yang memiliki resiko kerugian akibat pelanggaran ini, antara lain:

2. Pencipta dan pelaku karena tidak mendapatkan pembayaran sejumlah uang yang seharusnya mereka peroleh.

3. Penerbit dan produser rekaman karena tidak mendapatkan keuntungan dan investasi finansial dan keahlian yang telah mereka tanamkan.

4. Penjual dan distributor karena tidak dapat bersaing secara sehat dengan pihak lain yang melakukan pelanggaran.

5. Konsumen dan masyarakat karena membeli ciptaan yang berkualitas rendah dan tidak mendapatkan semangat untuk menciptakan sesuatu yang baru atau lebih baik. ${ }^{21}$

Sering kita mendengar istilah 'pelanggaran hak cipta'. Sebab di dunia modern sekarang ini, kekayaan manusia bukan lagi hanya berwujud benda fisik, tapi juga dapat berbentuk kekayaan lain tak berwujud, misalnya dalam bentuk hak kekayaan Intelektual (HAKI). Salah satu bentuk Hak Kekayaan Intelektual adalah hak cipta, di samping ada hak-hak lain seperti hak paten, rahasia dagang dan lain sebagainya. Semua hak-hak tersebut memiliki perbedaan masing-masing dan semua dilindungi oleh Hak kekayaan intelektual.

Pengertian yang dikemukakan dalam Undang- Undang No. 19 Tahun 2002 tentang

${ }^{21} \mathrm{htp} / \mathrm{www}$. dgp.go.id /artikel cleview/26/1/1997, Diakses, 03 Maret 2019.
Hak Cipta, Hak Cipta adalah hak eksklusif bagi Pencipta atau penerima hak untuk mengumumkan atau memperbanyak Ciptaannya atau memberikan izin untuk itu dengan tidak mengurangi pembatasanpembatasan menurut peraturan perundangundangan yang berlaku.

Pada dasarnya, hak cipta merupakan "hak untuk menyalin suatu ciptaan". Hak cipta dapat juga memungkinkan pemegang hak tersebut untuk membatasi penggandaan tidak sah atas suatu ciptaan.

Penegakan hukum yang diakibatkan oleh suatu pelanggaran hak cipta dapat ditempuh melalui dua jalur, yaitu jalur keperdataan dengan mengajukan gugatan perdata dan jalur kriminalitas dengan tuntutan pidana. Kedua jalur ini bisa digunakan sekaligus, artinya di samping melakukan tuntutan pidana oleh penegak hukum untuk kepentingan negara/masyarakat Pihak pelanggar hukum yang telah dijatuhkan hukum keperdataan (ganti rugi, dan sebagainya) masih dapat diajukan ke peradilan pidana, dan juga sebaliknya dalam undang-undang hak cipta.

Pengajuan tuntutan pelanggaran hak cipta dapat juga dilakukan secara pidana. Undang-udang hak cipta telah merumuskan perbuatan-perbuatan yang dikategorikan sebagai tindak pidana hak cipta. Tindak pidana hak cipta ini dijadikan sebagai delik biasa, maka dengan demikian penindakan dapat segera dilakukan tanpa perlu menunggu adanya pengaduan dari pemegang hak cipta yang haknya dilanggar. "Undang-undang Hak Cipta tidak memuat secara rinci jenis-jenis tindak pidana hak cipta yang jelas dalam lingkup ilmu pengetahuan, kesenian dan kesusastraan"22.

22Widyopramono, 1992, Op.cit, h 15. 
Media Komunikasi dan Informasi Hukum dan Masyarakat

Gugatan pelanggaran hak cipta, dilakukan atau diajukan pada pengadilan niaga (pasal 56 ayat 1) dan pengadilan niaga ini adalah pengadilan dimana pihak tergugat yang melakukan pelanggaran berdomisili atau bertempat tinggal. Berlainan halnya dengan gugatan atas pendaftaran yang ditolak, maka gugatan diajukan kepada Pengadilan Niaga Jakarta Pusat, ini dikarenakan pendaftaran ciptaan diajukan kepada Menteri Kehakiman melalui Direktorat Hak Cipta, Paten dan Merek Departemen Kehakiman yang berkedudukan di Jakarta.

Pengajuan gugatan atas pelanggaran hak cipta tidak menutup kemungkinan bila mengandung unsur pidana negara mempunyai hak untuk melakukan tuntutan (pasal 66), dalam hal ini dilakukan melalui tahapan proses tuntutan pidana pada umumnya. Dimungkinkan negara (aparat penegak hukum) melakukan tuntutan pidana, sebelumnya sifat delik hak cipta digolongkan sebagai delik aduan artinya pihak aparat penegak hukum baru dapat turun tangan menyelesaikannya apabila pihak yang dilanggar mengajukan pengaduan, maka aparat penegak hukum baru bertindak. ${ }^{23}$

Penegakan hukum hak cipta Indonesia yang telah dilengkapi dengan perangkat perundang-undangan yang memadai yaitu UUHC yang masih perlu ditindak lanjuti dengan tindakan-tindakan untuk peningkatannya. Misalnya, dengan mengadakan perluasan jaringan HAKI melalui kerja sama instansi yang mau tidak mau harus dilaksanakan. Terutama dalam kondisi yang bertujuan melindungi konsumen dari barang-barang hasil pembajakan produk-produk industri hiburan seperti lagu-lagu.

${ }^{23}$ Ajib Rosidi, 2015, Undang-Undang Hak Cipta 2014, Pandangan Seorang Awam, Djambatan, Jakarta, h. 37
Pada kenyataannya institusi-institusi penegak hukum di Indonesia, seperti Direktorat Jenderal HAKI, Pengadilan, Polisi dan Kejaksaan di Indonesia mempunyai yurisdiksi sendiri-sendiri dan wewenang yang dibutuhkan dalam hal ini perlindungan HAKI. Tetapi di sisi lain, adalah suatu kenyataan bahwa masing - masing yurisdiksi yang dimiliki dan wewenang yang diberikan kepada institusi-institusi ini dibatasi dengan cakupan dan tujuan wewenang yang diberikan pada institusi tersebut. Dengan kata lain misalnya, kasus pelanggaran hak cipta lagu memerlukan bantuan dan kerja sama yang cepat dan tepat dari institusi yang terkait.

Memberikan pemahaman yang intensif tentang hak cipta masyarakat untuk menumbuhkan kesadaran masyarakat dan anak didik, dan seluruh jajaran penegak hukum. Pemahaman tentang hak cipta, penyebar luasannya hendaknya juga diberikan kepada para pelaku hak cipta. Dan juga kepada penggunaan ciptaan perlu disosialisasikan tentang sistem hak cipta beserta hak - hak dan kewajiban serta perlindungan hukumnya. ${ }^{24}$

\section{Implementasi Perlindungan Hak Cipta Dalam Undang - Undang Republik Indonesia Nomor 28 Tahun 2014}

Didalam perlindungan hak cipta terdapat beberapa aturan dasar yang melindungi pelanggaran-pelanggaran yang dilakukan oleh siapa saja yang melanggar dalam bidang hak cipta diantaranya adalah peraturan pemerintah melalui UUHC ataupun melalui dewan hak cipta. Salah satu sifat atau asas yang melekat pada hak kebendaan adalah, asas lain droit de suite, asas hak mengikuti bendanya. Hak untuk menuntut akan mengikuti benda tersebut secara terus menerus ditangan siapapun benda itu berada.

${ }^{24}$ Muhamad Firmansyah, 2008, Tata Cara Mengurus Haki, Visimedia, Jakarta, h. 30. 
Media Komunikasi dan Informasi Hukum dan Masyarakat

Perlindungan hukum dapat dikatakan sangat penting dan menjadi hak bagi tiap warga Negara. Beberapa ahli hukum memaparkan pendapatnya mengenai pengertian dari perlindungan hukum, salah satunya ialah Satjipto Raharjo. Satjipto Raharjo mendefinisikan perlindungan hukum adalah "memberikan pengayoman kepada hak asasi manusia yang dirugikan orang lain dan perlindungan tersebut diberikan kepada masyarakat agar mereka dapat menikmati semua hak-hak yang diberikan oleh hukum."25

Jika dicermati perlindungan hak cipta sebagai hak kebendaan yang immateril maka akan teringat kepada hak milik. Hak milik ini menjamin kepada pemilik untuk menikmati dengan bebas dan boleh pula melakukan tindakan hukum dengan bebas terhadap miliknya itu. Objek hak milik itu dapat berupa hak cipta sebagai hak kekayaan immateril. Terhadap hak cipta, si pencipta atau sipemegang hak dapat mengalihkan untuk seluruhnya atau sebagian hak cipta itu kepada orang lain, dengan jalan pewarisan, hibah atau wasiat atau dengan cara lain. (Pasal $3 \cup U H C$ ).

Hal ini membuktikan bahwa hak cipta itu merupakan hak yang dapat dimiliki, dapat menjadi objek pemilikan atau hak milik dan oleh karenanya terhadap hak cipta itu berlaku syaratsyarat pemilikan, baik mengenai cara penggunaannya maupun cara pengalihan haknya. Kesemua itu undang-undang akan memberikan perlindungan sesuai dengan sifat dan hak tersebut. Dapat pula dipahami, bahwa perlindungan yang diberikan oleh undangundang terhadap hak cipta adalah untuk menstimulir atau merangsang aktivitas para

${ }^{25}$ Perlindungan Hukum Menurut Para Ahli, Tesis Hukum.com, Google, Diakses, tanggal. 03 Maret 2019. pencipta agar terus mencipta dan lebih kreatif. Lahirnya ciptaan baru atau ciptaan yang sudah ada sebelumnya harus didukung dan dilindungi oleh hukum. "Wujud perlindungan itu dikukuhkan dalam undang-undang dengan menempatkan sanksi pidana terhadap orang yang melanggar hak cipta dengan cara melawan hukum." ${ }^{26}$ Sanksi Pidana dalam kejahatan pembajakan Hak Cipta itu sendiri sudah diatur di Pasal 72 dalam ayat 1 sampai dengan ayat 9. UUHC Indonesia menempatkan tindak pidana hak cipta itu sebagai delik biasa yang dimaksudkan untuk menjamin perlindungan yang lebih baik dari sebelumnya, di mana sebelumnya tindak pidana hak cipta dikategorikan sebagai delik aduan. Perubahan sifat delik ini adalah merupakan kesepakatan masyarakat yang menyebabkan suatu pelanggaran bisa diperkarakan ke pengadilan secara tepat dan tidak perlu menunggu pengaduan terlebih dahulu dari pemegang hak cipta.

\section{Akibat Hukum Atas Tindakan Perbanyakan Lagu Hilang Tanpa Perjanjian Lisensi Ditinjau Dari Undang- Undang Republik Indonesia Nomor 28 Tahun 2014}

\section{A. Perlindungan Hukum Hak Cipta Tindakan Perbanyakan Lagu Tanpa Perjanjian Lisensi}

Perbuatan yang dianggap sebagai pelanggaran atas Hak Cipta terdaftar juga telah diatur dalam UUHC, yakni dalam Pasal 43, yang berbunyi:

${ }^{26}$ OK. Saidin, Aspek Hukum Hak Kekayaan Intelektual (Intellectual Property Rights)., PT. Raja Grafindo Persada, Jakarta, 2007. h. 112. 
Media Komunikasi dan Informasi Hukum dan Masyarakat

Perbutan yang tidak dianggap sebagai pelanggaran hak cipta meliputi:

a. Pengumuman, Pendistribusian, Komunikasi, dan/atau Penggandaan lambang negara dan lagukebangsaan menurut sifatnya yang asli;

b. Pengumuman, Pendistribusian, Komunikasi, dan/atau Penggandaan segala sesuatu yang dilaksanakanoleh atau atas nama pemerintah, kecuali dinyatakan dilindungi oleh peraturan perundang-undangan, pernyataan pada Ciptaan tersebut, atau ketika terhadap Ciptaan tersebut dilakukan Pengumuman,Pendistribusian,

Komunikasi, dan/atau Penggandaan;

c. pengambilan berita aktual, baik seluruhnya maupun sebagian dari kantor berita, Lembaga Penyiaran, dansurat kabar atau sumber sejenis lainnya dengan ketentuan sumbernya harus disebutkan secara lengkap;atau

d. pembuatan dan penyebarluasan konten Hak Cipta melalui media teknologi informasi dan komunikasi yangbersifat tidak komersial dan/atau menguntungkan Pencipta atau pihak terkait, atau Pencipta tersebutmenyatakan tidak keberatan atas pembuatan dan penyebarluasan tersebut.

e. Penggandaan, Pengumuman, dan/atau Pendistribusian Potret Presiden, Wakil Presiden, mantanPresiden, mantan Wakil Presiden, Pahlawan Nasional, pimpinan lembaga negara, pimpinankementerian/lembaga

pemerintah non kementerian, dan/atau kepala daerah dengan memperhatikanmartabat dan kewajaran sesuai dengan ketentuan peraturan perundang-undangan.

Perlindungan hukum terhadap Hak Cipta pada dasarnya dimaksud sebagai upaya untuk mewujudkan iklim yang lebih baik bagi tumbuh dan berkembangnya gairah mencipta di bidang ilmu pengetahuan, seni dan satra. Menyadari akan hal tersebut, pemerintah Indonesia secara terus menerus berusaha untuk menyesuaikan diri dengan perkembangan yang ada, baik perkembangan di bidang ekonomi maupun di bidang teknologi.
Dengan turut serta Indonesia menandatangani perjanjian World Trade Internasional termasuk perjanjian tentang Trade Related Aspect of Intelectual Property Rights, maka Undang-Undang Hak Cipta perlu menyesuaikan diri untuk memenuhi kewajiban Internasional yang sudah kita terima melalui kedua organisi tersebut, termasuk di dalamnya adalah ketentuan yang berkaitan dengan perlindungan Hak Milik Intelektual. ${ }^{27}$

Perlindungan hukum yang ada merupakan upaya yang diatur oleh UndangUndang guna mencegah terjadinya pelanggaran Hak Kekayaan Intelektual oleh orang yang tidak berhak. Pelanggar yang telah melakukan pelanggaran harus diproses secara hukum dan jika terbukti harus dijatuhi hukuman sesuai dengan Undang-Undang di bidang Hak Kekayaan Intelektual yang dilanggar. Untuk memahami apakah perbuatan itu merupakan pelanggaran Hak Kekayaan Intelektual, perlu dipenuhi unsur-unsur sebagai berikut:

1. Larangan Undang-Undang Perbuatan yang dilakukan oleh seorang pengguna Hak Kekayaan Intelektual dilarang dan diancam dengan hukuman oleh UndangUndang;

2. Izin (Lisensi)

Penggunaan Intelektual Hak Kekayaan persetujuan (lisensi) dari pemilik atau pemegang hak terdaftar;

3. Pembatasan Undang-Undang Penggunaan Hak Kekayaan Intelektual melampaui batas ketentuan yang telah ditetapkan oleh UndangUndang;

4. Jangka Waktu Penggunaan Hak Kekayaan Intelektual dilakukan dalam jangka waktu perlindungan yang telah

${ }^{27}$ Sudargo Gautama, Rizawanto Winata, 1997, Konvensi-Konvensi Hak Milik Intelektual Baru Untuk Indonesia, Bandung: Citra Aditya Bakti, h. 1. 
Media Komunikasi dan Informasi Hukum dan Masyarakat

ditetapkan oleh Undang-Undang atau perjanjian tertulis. ${ }^{28}$

Pelanggaran Hak Cipta sudah terjadi sejak berlakunya Auteurswet 1912 dan semakin meningkat hingga berlakunya UUHC 1982. Auteurswet pada hakikatnya tidak mempunyai dampak terhadap perlindungan Hak Cipta. Mengingat masyarakat Indonesia pada waktu itu, yaitu masa berlakunya Auteurswet tersebut belum cukup mencapai tingkat pemahaman mengenai arti dan kegunaan Hak Cipta. Terdapat hambatan kultural atas perlindungan Hak Cipta pada masa itu. Perlindungan Hak Cipta secara individual pada hakikatnya merupakan hal yang tidak di kenal di Indonesia. Suatu ciptaan oleh masyarakat di anggap secara tradisional sebagai milik bersama. Tumbuhnya kesadaran bahwa ciptaan itu perlu perlindungan hukum setelah dihadapinya bahwa ciptaan itu perlu mempunyai nilai ekonomi. ${ }^{29}$

Umumnya, hak cipta dilanggar jika materi hak cipta tersebut digunakan tanpa izin dari pencipta yang mempunyai hak eksklusif dari penciptanya. Untuk terjadinya suatu pelanggaran hak cipta, harus ada kesamaan antara dua ciptaan yang ada. Namun, pencipta atau pemegang hak cipta harus membuktikan bahwa karyanya telah dijiplak, atau karya lain tersebut berasal dari karyanya.

Pelanggaran hak cipta dapat berupa perbuatan mengambil, mengutip, merekam, memperbanyak, atau mengumumkan sebagai atau seluruh ciptaan orang lain tanpa izin pencipta atau pemegang hak cipta, atau yang dilarang Undang-Undang. Dilarang UndangUndang artinya Undang-Undang tidak

${ }^{28}$ Abdulkadir Muhammad, 1994, Hukum Harta Kekayaan, Bandung: Penerbit PT. Citra Aditya Bakti.

${ }^{29}$ Harsono Adisumitro, Op.Cit., h. 49. memperkenankan perbuatan itu dilakukan karena:

a. Merugikan pencipta atau pemegang hak cipta, misalnya memfotokopi sebagian ciptaan orang lain kemudian diperjualbelikan kepada masyarakata; atau

b. Merugikan kepentingan Negara, misalnya mengumumkan ciptaan yang bertentangan dengan kebijakan pemerintah di bidang pertanahan dan keamanan; atau

c. Bertentangan dengan ketertiban umum dan kesusilaan, misalnya memperbanyak dan menjual Compact Disc (CD) porno. ${ }^{30}$

Hak cipta juga di langgar jika seluruh atau sebagian substansial dari suatu ciptaan yang dilindungi hak cipta diperbanyak. Pengadilan akan menetukan apakah suatu bagian yang di tiru merupakan bagian subtansial dengan meneliti apakah bagian yang digunakan itu penting, memiliki unsur pembeda atau bagian yang mudah dikenali.

Perbuatan pelanggaran hak cipta pada dasarnya ada 2 kelompok yaitu:

a. Dengan sengaja dan tanpa hak mengumumkan, memperbanyak suatu ciptaan, atau member izin untuk itu. Termasuk perbuatan pelanggaran ini antara lain melanggar untuk mengumukan, memperbanyak atau member izin untuk itu setiap ciptaan yang bertentangan dengan kebijaksanaan pemerintah di bidang pertanahan keamana Negara, kesuisilaan atau ketertiban umum.

b. Dengan sengaja memamerkan, mengedarkan, atau menjual kepada umum suatu ciptaan atau barang hasil pelanggaran hak cipta. Termasuk perbuatann pelanggaran ini antara lain penjualan buku dan kaset atau Compact Disc (CD) bajakan.

${ }^{30}$ Ibid., h. 220. 
Media Komunikasi dan Informasi Hukum dan Masyarakat

Salah satu bentuk kejahatan atau pelanggaran di bidang industri rekaman suara yang menimbulkan kerugian yang cukup besar bagi pemegang hak cipta dan hak terkait adalah pembajakan (piracy). Meningkatnya angka pengangguran secara signitika di Indonesia semenjak krisi ekonomi, di samping lemahnya penegakan hukum, telah membuat pembajakan tumbuh dengan pesat dan menciptakan banyak lapangan kerja sebagai pembuat, penyalur, pengecer. Mungkin lapangan kerja tersebut sebagian besar diciptakan oleh industri barang bajakan yang menggunakan media optik. Kebutuhan dalam negeri terhadap barangbarang tersebut telah terpenuhi dengan angka lebih dari 400 juta keping Video Compact Disc atau Compact Disc bajakan. ${ }^{31}$

Pembajakan di bidang industri rekaman adalah tindak pidana kejahatan pelanggaran hak cipta. Pekerjaannya liar, tersembunyi, tidak diketahui orang banyak, apalagi oleh petugas pajak. Pembajakan tidak mungkin membayar pajak kepada Negara. Pembajak ciptaan atau rekaman di samping merugikan pencipta atau pemegang hak cipta juga merugikan Negara. Pembajakan merupakan salah satu dampak negatif kemajuan ilmu pengetahuan dan teknologi di bidang grafika dan elektronika yang dimanfaatkan secara melawan hukum (ilegal).Pembaja kan lagu atau musik dengan menggunakan Compact Disc (CD) adalah merupakan salah satu jenis alat daripada cakram optik (Optical Disc).

Pemegang hak cipta juga berhak meminta kepada Pengadilan Niaga agar memerintahkan penyerahan seluruh atau sebagian penghasilan yang diperoleh dari penyelenggaraan ceramah dan pertemuan ilmiah lainnya, atau pertunjukan atau pameran

\footnotetext{
${ }^{31}$ Tim Lindsdey, et.al, Op.Cit., h. 63.
}

karya yang merupakan hasil pelanggaran hak cipta atau dengan cara melanggar hak cipta tersebut. Untuk mencegah kerugian yang lebih besar pada pihak yang haknya dilanggar, hakim dapat memerintahkan pelanggaran untuk menghentikan kegiatan pembuatan, perbanyakan, penyiaran, pengedaran, dan penjualan ciptaan atau barang yang merupakan hasil pelanggaran hak cipta (Pasal 56 UUHC).

\section{B. Upaya Penegakan Hukum Apabila Terjadi Pelanggaran Terhadap Hasil Rekaman Suara}

Penegakan hukum sebagai usaha menjalankan hukum dapat mempunyai arti sempit, arti luas, dan arti yang tidak terbatas. Dalam arti sempit penegakan hukum adalah menjalankan hukum oleh polisi, sebagaimana pengertian orang awam tentang hukum. Dalam arti luas penegakan hukum adalah menjalankan hukum oleh alat-alat perlengkapan negara, yakni kepolisian, kejaksaan, kehakiman. Pengertian penegakan hukum yang tidak terbatas adalah tugas dari pembentukan Undang- Undang, hakim, jaksa, pengacara, aparat pemerintah pamong praja, lembaga permasyarakatan, dan aparat eksekusi, serta setiap orang yang menjalankan hukum yaitu badan resmi dan setiap orang yang bersangkutan dengan proses berjalannya hukum. ${ }^{32}$ Banyak hambatan yang dihadapi oleh aparat penegak hukum dalam menegakkan UUHC. Permasalahan tersebut baik permasalahan yuridis maupun non yuridis. Hukum tidak berdiri sendiri, banyak faktor yang menyertainya dan berpengaruh terhadap bekerjanya hukum. Pada dasarnya,

${ }^{32}$ Bambang Poernomo, 1984, Orientasi Hukum Acara Pidana, Yogyakarta: Amarta Buku, h. 119. 
Media Komunikasi dan Informasi Hukum dan Masyarakat

permasalahan penegakan hukum terletak pada faktor-faktor yang mungkin berpengaruh.

Menurut Soerjono Soekanto, ada beberapa faktor yang dapat mempengaruhi bekerjanya hukum yaitu:

1. Faktor hukumnya sendiri, yaitu dalam hal ini dibatasi oleh Undang-Undang Hak Cipta;

2. Faktor penegak hukum yakni pihakpihak yang membentuk dan menerapkan hukum;

3. Faktor masyarakat, yakni lingkungan dimana hukum itu berlaku atau diterapka;

4. Faktor kebudayaan, yakni sebagai hasil karya, cipta dan rasa yang didasarkan pada karsa manusia didalam pergaulan hidup. ${ }^{33}$

Peranan pemerintah dalam upaya penegakan hukum terhadap Hak Cipta pada dasarnya dimaksudkan sebagai upaya untuk mewujudkan iklim yang lebih bagi tumbuh dan berkembangnya gairah mencipta di bidang ilmu pengetahuan, seni dan sastra. Menyadari akan hal tersebut, pemerintah Indonesia secara terus menerus berusaha untuk memperbaharui peraturan perundang-undangan di bidang Hak Cipta untuk menyesuaikan diri dengan perkembangan yang ada, baik perkembangan di bidang ekonomi maupun teknologi.

Pemegang hak cipta juga berhak meminta kepada Pengadilan Niaga agar memerintahkan penyerahan seluruh atau sebagian penghasilan yang diperoleh dari penyelenggaraan ceramah dan pertemuan ilmiah lainnya, atau pertunjukan atau pameran karya yang merupakan hasil pelanggaran hak cipta atau dengan cara melanggar hak cipta tersebut. Untuk mencegah kerugian yang lebih besar pada pihak yang haknya dilanggar, hakim dapat memerintahkan pelanggaran untuk menghentikan kegiatan pembuatan,

${ }^{33}$ Soerjono Soekanto, Op.Cit., h. 2. perbanyakan, penyiaran, pengedaran, dan penjualan ciptaan atau barang yang merupakan hasil pelanggaran hak cipta (Pasal 56 UUHC).

Upaya penegakan hukum yang dilakukan merupakan langkah awal untuk mengatasi meluasnya pelanggaran hak cipta yang dalam hal ini terhadap hasil rekaman suara yang dikonversi dalam bentuk CD yang marak diperjualbelikan dipasaran secara bebas. Hal ini juga memberikan suatu pencerahan dan pemahaman kepada masyarakat akan arti pentingnya mengahargai hasil karya cipta yang ada, sehingga mematikan keinginan pencipta untuk terus berkarya. Majunya perkembangan di bidang teknologi informasi dan telekomunikasi bukan merupakan sarana untuk melakukan pelanggaran tetapi merupakan suatu faktor untuk memperluas wawasan ilmu pengetahuan.

\section{Akibat Hukum Atas Tindakan Perbanyakan Lagu Tanpa Perjanjian Lisensi}

Dalam Pelaksanaan Perjanjian Lisensi Perjanjian antara pencipta musik/lagu dan produser rekaman berdasarkan UUHC merupakan suatu perjanjian lisensi karya cipta lagu yang memperoleh persetujuan dari penciptanya untuk digunakan / dipakai oleh pihak lain untuk kepentingan komersial. Pada prinsipnya lisensi menurut UUHC adalah ijin yang diberikan oleh pemegang hak cipta atau pemegang hak terkait kepada pihak lain untuk mengumumkan dan / atau memperbanyak ciptaannya atau produk hak terkaitnya dengan persyaratan tertentu.

Di dalam UUHC yang dimaksud dengan lisensi adalah ijin tertulis yang diberikan oleh pemegang hak cipta atau pemilik hak terkait kepada pihak lain untuk melaksanakan hak ekonomi atas ciptaannya atau produk hak terkait 
Media Komunikasi dan Informasi Hukum dan Masyarakat

dengan syarat tertentu. Dari pengertian lisensi yang termuat di dalam kedua ketentuan UUHC tersebut di atas dapat dikatakan bahwa lisensi adalah ijin yang diberikan oleh pemegang hak cipta atau hak terkait kepada pihak lain untuk mengumumkan atau memperbanyak ciptaannya atau produk hak terkaitnya dengan persyaratan tertentu. ${ }^{34}$

Di dalam melindungi pencipta dan suatu hak cipta atas lagu di dalam suatu perjanjian antara pencipta musik/lagu dengan produser rekaman akan terlibat beberapa unsur / pihak yaitu :

1. Pencipta mengalihkan hak cipta lagu/musiknya kepada produser rekaman suara untuk dieksploitasi, yaitu direkam, digandakan dan dijual.

2. Produser rekaman suara dengan bantuan penata musik (arranger), musisi, dan penyanyi merekam ciptaan musik tersebut dengan irama pokok atau irama varian lain mislnya Jazz, Bosas, Keroncong, Jaipong, Dangdut, Chacha, Cadhut, Latin, Blues, Hawaiian atau irama lainnya ke dalam bentuk master rekaman musik.

3. Master rekaman musik ini oleh produser rekaman diserahkan kepada perusahaan pengganda master rekaman untuk digandakan atua diperbanyak dalam bentuk kaset atau CD atau media rekam lainnya. ${ }^{35}$

Dengan demikian dapat dikatakan bentuk perlindungan hukum yang diberikan oleh UUHC terhadap pencipta lagu dari perbuatan melawan hukum yang dilakukan oleh produser rekaman suara dalam pelaksanaan perjanjian lisensi adalah sebagai berikut :

1. Hak cipta atas suatu ciptaan musik/lagu tetap berada di tangan pencipta selama

${ }^{34}$ Richard Burton Simatupang, Aspek Hukum Dalam Bisnis, Rineka Cipta, Jakarta, 2007, h. 80

${ }^{35}$ Adrian Sutedi, Hak Atas Kekayaan Intelektual, Sinar Grafika, Jakarta, 2009, h. 35 kepada pembeli ciptaan itu tidak diserahkan seluruh hak cipta dari pencipta itu.

2. Suatu ciptaan tidak boleh diubah judulnya, anak judul, walaupun hak ciptanya telah diserahkan kepada pihak lain, kecuali dengan persetujuan pencipta atau dengan persetujuan ahli warisnya dalam hal pencipta dalam hal pencipta telah meninggal dunia, termasuk hak supaya nama pencipta tetap dicantumkan dalam ciptaanya tersebut.

3. Pencipta atau ahli warisnya berhak menuntut pemegang hak cipta apabila terjadi nama pencipta tidak dicantumkan dalam ciptaan, terjadi perubahan atas judul dan anak judul ciptaan tanpa ijin dari pencipta atau ahli warisnya apabila pencipta telah meninggal dunia.

4. Pencipta atau ahli warisnya berhak menuntut pihak lain yang menggunakan lagu ciptaannya secara komersil tanpa izin pencipta atau ahli warisnya.

5. Pengajuan gugatan terhadap perbuatan melawan hukum hak cipta yang dilakukan oleh produser rekaman atau pihak lain diajukanoleh pencipta atau ahli warisnya bila pencipta telah meninggal dunia ke Pengadilan Niaga.

Dari ketentuan tersebut di atas dapat dikatakan bahwa perlindungan hukum terhadap suatu ciptaan musik/lagu tetap berada di tangan penciptanya meskipun ciptaan tersebut telah dijual kepada pihak lain. Dalam hal ini pemberian hak cipta hanya menyangkut tentang penggunaan hasil ciptaan tersebut untuk kepentingan komersial, sedangkan nama pencipta tetap harus dicantumkan dan hasil ciptaan tidak dapat dirubah oleh pembeli hak cipta tanpa ijin dari pencipta. Apabila terjadi perubahan ciptaan ataupun pemegang hak cipta tidak mencantumkan nama pencipta maka 
Media Komunikasi dan Informasi Hukum dan Masyarakat

pencipta atau ahli warisnya dapat melakukan penuntutan pengguna hak cipta yang tidak mencantumkan nama pencipta ataupun merubah dari hasil ciptaan dari pencipta tersebut tanpa izin dari pencipta atau ahli warisnya.

\section{KESIMPULAN DAN SARAN}

\section{A. Kesimpulan}

1. Implementasi Perlindungan hukum terhadap pemegang hak cipta atas karya cipta lagu ditinjau dari Undang-Undang Republik Indonesia Nomor 28 Tahun 2014 bahwa didalam perlindungan hak cipta terdapat beberapaaturan dasar yang melindungi hasil karya cipta yang dilakukan oleh siapa saja yang melanggar dalam bidang hak cipta diantaranya adalah peraturan pemerintah melalui UUHC ataupun melalui dewan hak cipta. Salah satu sifat atau asas yang melekat pada hak kebendaan adalah asas lain droit de suite, asas hak mengikuti benda tersebut secara terus menerus ditangan siapapun benda itu berada. Perlindungan hukum dapat dikatakan sangat penting dan menjadi hak bagi tiap warka negara.

2. Akibat hukum atas tindakan perbanyakan lagu hilang tanpa perjanjian lisensi ditinjau dari Undang-Undang Republik Indonesia Nomor 28 Tahun 2014 di atur dalam Pasal 72, dimana upaya penegakan hukumnya oleh pemerintah dengan memberikan sanksi pidana dan sanksi perdata dengan tuntutan ganti rugi. Peranan pemerintah dalam penegakan hukum hak cipta guna menangani pembajakan Hak Cipta Lagu atau Musik adalah dengan memberikan sanksi-sanksi yang tegas berupa perampasan dan pemusnahan barang hasil pembajakan Hak Cipta yang dilakukan oleh pemerintah, sebagaimana yang telah diatur dalam Undang-Undang Hak Cipta.

3. Mahkamah Agung mempertimbangkan alasan-alasan peninjauan kembali dari Pemohonbahwaalasan-alasan tersebut tidak dapat dibenarkan, oleh karena judex juris tidak melakukan kekhilafan atau kekeliruan nyata memutus perkara a quo. Walaupun judex facti sudah memeriksa perkara tersebut dengan lengkap, akan tetapi judex facti belum memutus pokok perkaranya dan judex juris berwenang untuk memerintahkan judex facti agar membuka kembali persidangan dan memutus perkara tersebut.Pertimbangan judex juris sudah tepat dan benar, berdasarkan pertimbangan tersebut, permohonan peninjauan kembali yang diajukan oleh Pemohon: Koharudin al. Kohar Kahler tersebut harus di tolak.

\section{B. Saran}

1. Diharapkan perlindungan terhadap karya cipta lagu terdaftar lebih diperhatikan lagi terutama terhadap usaha karaoke yang semakin banyak disetiap kota di Indonesia.

2. Diharapkan pemerintah memberikan akibat hukum terhadap para pelanggar hak cipta terdaftar bener-bener memberikan efek jera sehingga dapat mengurangi tingkat pelanggaran kedepannya.

3. Diharapkanmajelis hakim dalam memberikan putusan terhadap pelanggar hak cipta dapat memberikan rasa aman kepada pemegang hak cipta agar haknya tidak lagi dilanggar. 
Media Komunikasi dan Informasi Hukum dan Masyarakat

\section{Daftar Bacaan}

\section{A. Buku}

Adisumarto, Harsono, Hak Milik Intelektual kususnya Hak Cipta, Akademik Pressindo, Jakarta

Ali, Achmad dan Wiwie Hariyani, Menjelajahi Kajian Empiris Terhadap Hukum, PrenadaKencana Media Group, Jakarta, 2012

Atmadja, Hendra Tanu, 2003, Hak Cipta Lagu, Penerbit Pasca Sarjana Universitas Indonesia, Jakarta

Audah, Husain, 2004, Hak Cipta dan Karya Musik, PT Pustaka Litera Antar Nusa, Jakarta

Damian, Eddy, Hukum Hak Cipta, Edisi Ketiga, PT Alumni, Bandung, 2009.

Dirjosisworo, Soedjono, Pengangtar IImu Hukum, Rajawali Pers, Jakarta, 2013

Djaja, Ermansyah, 2009 Hukum Hak Kekayaan Intelektual, Sinar Grafika, Jakarta

Faisal, IImu Hukum, Sebuah Kajian Kritis, Filsafat, Keadilan dan Tafsir, Thafamedia, Yokyakarta, 2015

Firmansyah, Muhamad, 2008, Tata Cara Mengurus Haki, Visimedia, Jakarta

Garner, Bryan A. Black's Law Dictionary, 7th Edition (Minnesota: West Group, 1999)

Gautama, Sudargo, Rizawanto Winata, 1997, Konvensi-Konvensi Hak Milik Intelektual Baru Untuk Indonesia, Bandung: Citra Aditya Bakti

H.R. Ridwan, Hukum Adminitrasi Negara, Rajawali Pers, Jakarta, 2006

H.S, Salim dan Erlies Septiana Nurbani, Penerapan Teori Hukum Pada Penelitian Desertasi dan Tesis, PT. Raja Grafindo Persada, Jakarta, 2014

Harahap, M. Yahya, Kekuasaan Mahkamah Agung Pemeriksaan Kasasi dan Peninjauan Kembali Perkara Perdata, Jakarta: Sinar Grafika, 2008

Harjowidigo, Rooseno,1997, Mengenal Hak Cipta Indonesia, Pustaka Sinar Harapan, Jakarta
Hasibuan, Otto, 2007, Hak Cipta di Indonesia Tinjauan Khusus Hak Cipta Lagu, Neighbouring Rights, dan Collecting Society, PT. Alumni, Bandung

Hornby, A.S, dan E. C. Parnwell, Oxford Progressive English Reader's Dictionary, Indonesian Edition (Kuala Lumpur: Oxford University Press dan P.T. Indira, 1972)

Kansil, C.S.T. Pengantar IImu Hukum Dan Tata Hukum Indonesia, Balai Pustaka, Jakarta, 2007

Lindsey, Tim, et.al., Hak Atas Kekayaan Intelektual (Suatu Pengantar),PT. Alumni, Bandung, 2011

Margono, Suyud. 2010. Hukum Hak Cipta Indonesia: Teori dan Analisis Harmonisasi Ketentuan WTO-TRIPs Agreement. Galia Indonesia, Bogor

Marieke, Joost Smiers, van Schijndel, 2012, Dunia Tanpa Hak Cipta, Jogjakarta

Marzuki, Peter Mahmud, Penelitian Hukum, Jakarta: Kencana Prenada Media, Jakarta, 2010

Pengantar IImu Hukum, Prenada Kencana Media Group, Jakarta, 2008

Maulana, Insan Budi, Ridwan Khairandy, Nurjihad, 2000, Kapita Selekta Hak Kekayaan Intelektual, Pusat Stusi Hukum Universitas Islam Yogyakarta bekerjasama dengan Yayasan Klinik HAKI Jakarta

Mertokusumo, Sudikno, Penemuan Hukum Sebuah Pengantar, Liberty, Yogyakarta, 2001

Muhammad, Abdulkadir, 1994, Hukum Harta Kekayaan, Bandung: Penerbit PT. Citra Aditya Bakti.

Munandar, Haris Dan Sally Sitanggang, 2008, Mengenal Hak Kekayaan Intelektual (Hak Cipta, Paten, Merek Dan SelukBeluknya), Erlangga, Jakarta

N.D, Mukti Fajar dan Yulianto Achmad, Dualisme Penelitian Hukum Normatif \& Empiris, Pustaka Pelajar, Yogyakarta, 2010 
Media Komunikasi dan Informasi Hukum dan Masyarakat

Nainggolan, Jogi, Energi Hukum Sebagai Faktor Pendorong Efektivitas Hukum, Refika Aditama, Jakarta, 2015

Poernomo, Bambang, 1984, Orientasi Hukum Acara Pidana, Yogyakarta: Amarta Buku

Rahardjo, Satjipto, IImu Hukum, Citra Aditya Bakti, Bandung, 2010

Ramli, Ahmad M. 2000, H.A.K.I Hak Atas Kepemilikan Intelektual, Teori Dasar Perlindungan Rahasia Dagang, Mandar Maju, Bandung

Rawls. J hon, A Theory of Justice, Teori Keadilan, Pustaka Pelajar, Yokyakarta, 2006

Rosidi, Ajib, 2015, Undang-Undang Hak Cipta 2014, Pandangan Seorang Awam, Djambatan, Jakarta

Saidin, OK., Aspek Hukum Hak Kekayaan Intelektual (Intellectual Property Rights)., PT. Raja Grafindo Persada, Jakarta, 2007

Setiawan, R. 1977, Pokok-Pokok Perikatan, Bandung: Bina Cipta

Simongkir, J.C.T. 1991, Melindungi Hak Pencipta yang Berfungsi Sosial, Suara Pembaharuan, Jakarta

Soekanto, Soerjono, Penelitian Hukum Normatif Suatu Tinjauan, Jakarta, Rajawali Pers, 2013

Soelistyo, Hendry, 2011, PLAGIARISME : pelanggaran hak cipta dan etika, yogyakarta : KANISIUS

Sutedi, Adrian, Hak Atas Kekayaan Intelektual. Sinar Grafika, Jakarta. 2009.

Syahrani, Ridwan, Rangkuman Inti Sari IImu Hukum, Citra Aditya Bakti, Bandung, 2013

Syarifin, Pipin, Dedah Jubaedah, 2004, Peraturan Hak Kekayaan Intelektual di Indonesia, Bandung: Pustaka Bani Quraisyi

Widjaja, Gunawan, Seri Hukum Bisnis - Lisensi (Jakarta: P.T. Raja Grafindo Persada, 2001)
Wigjosoebroto, Soetandyo, Hukum, Paradigma, Metode dan Dinamika Masalahnya, Elsam HuMa, Jakarta, 2002

\section{B. Peraturan perundang-undangan}

Undang - Undang Republik Indonesia Nomor 28 Tahun 2014 Tentang Hak Cipta

\section{Sumber Internet}

Anonim, "Perlindungan Hukum", www.statushukum.com, diakses 01 Desember 2018

Anonim, "Seputar Pengertian Perlindungan Hukum", Diakses melalui: seputar pengertian.blog.spot.com> Hukum > Perlindungan, tanggal 01 Desember 2018.

Fitri Hidayat, "Perlindungan Hukum Unsur Esensial dalam Suatu Negara Hukum", melalui www. ftirihidayat-ub.blogspot.com, diakses tanggal 01 Desember 2018.

"Ganti Rugi", 2014, (Kamus Bisnis), http://kamusbisnis.com/arti/ganti-

rugi/Diakses, tanggal. 03 Maret 2019

https://eprints.uny.ac.id/13360/3/BAB\%20II.PDF diakses pada tangga; 01 Desember 2018

http//www.dgp.go.id /artikel cleview/26/1/1997, Diakses, 03 Maret 2019.

http://netyernawaty.blogspot.com/2012/11/jangk a-waktu-perlindungan-hak-

cipta.htmlJumat, di posting tanggal 16 November 2011 dan diunduh tanggal 03 Maret 2013.

http://netyernawaty.blogspot.com/2012/11/meng kopi-musik-hak-cipta.html Jumat, di posting tanggal 16 November 2013 dan diunduh tanggal 03 Maret 2019.

http://budimansudharma.com/category/perbuata n-melawan-hukum/. Di posting tanggal 20 juni 2010 dan diunduh 03 Maret 2019.

Irwan Darwis, "Penegakan dan Perlindungan Hukum", Diakses melalui website: www.irwankaimoto.blogspot.com, tanggal 01 Desember 2018

Perlindungan Hukum Menurut Para Ahli, Tesis Hukum.com, Google, Diakses, tanggal. 03 Maret 2019 